\title{
Leaf water potential, nutritional status and must composition in grapes 'Pinot Nero' with and without irrigation
}

\author{
Potencial de água em folhas, estado nutricional e composição do mosto em viníferas 'Pinot Nero' \\ com e sem irrigação
}

\author{
Marlise Nara Ciotta ${ }^{\text {I }}$ Carlos Alberto Ceretta ${ }^{\text {II }}$ Massimo Tagliavini ${ }^{\text {III }}$ Damiano Zanotelli ${ }^{\text {III }}$

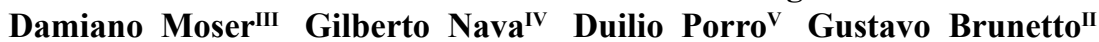 \\ - NOTE -
}

\section{ABSTRACT}

Irrigating vineyard soils can affect grapevine water potential, nutritional status, and must composition. This study aimed to evaluate leaf water potential, nutritional status, and must composition in cv. 'Pinot Nero' grapevines grown with and without irrigation. The experiment was conducted at a commercial vineyard of 'Pinot Nero' 828 grafted on $\mathrm{SO}_{4}$ rootstock, established in 2002 in Trento, Northern Italy. The treatments were irrigated (I) and non-irrigated (NI) throughout the 2013 crop season. The criteria evaluated were the water potential of the leaves, total nutrient content in the leaves and berries, and weight of 100 berries, as well as the total soluble solids content, $\mathrm{pH}$, and total titratable acidity of the must. Despite providing a less negative water potential for the grapevine leaves, irrigation did not affect the nutritional status or must composition, and it only slightly interfered with berry nutrient content.

Key words: nutrients, irrigation, Vitis vinifera.

\section{RESUMO}

A irrigação em solos de vinhedos pode afetar o potencial hídrico da videira, o estado nutricional e a composição do mosto. O trabalho objetivou avaliar o potencial de água em folhas, o estado nutricional e a composição do mosto, em videiras da cv. 'Pinot Nero', cultivadas com e sem irrigação. O experimento foi conduzido em um vinhedo comercial de 'Pinot Nero' 828 , enxertada sobre o porta enxerto $\mathrm{SO}_{4}$, implantado em $2002 \mathrm{em}$ Trento, Norte da Itália. Os tratamentos foram com irrigação (I) e sem irrigação (SI) ao longo da safra de 2013. Avaliou-se o potencial hídrico das folhas, o teor total de nutrientes em folhas e bagas, a massa de 100 bagas e, no mosto, foram avaliados o teor de sólidos solúveis totais, $\mathrm{pH}$ e acidez total titulável. A irrigação, apesar de proporcionar potencial de água menos negativo nas folhas da videira, não afetou o estado nutricional, a composição do mosto e pouco interferiu no teor de nutrientes na baga.

Palavras-chave: nutrientes, irrigação, Vitis vinifera.

In northern Italy, grapevines (Vitis vinifera L.) such as cv. 'Pinot Nero' are irrigated during plant growth, mainly during berry growth and ripening, which usually occur between August and September, when there is little rainfall (MARIANI et al., 2012). However, the impact of providing water to the soil on nutritional status and must composition of the grapevines, which affects wine quality, is poorly understood for this region. In irrigated vineyard soils, water availability in the soil is expected to favor adequate water uptake by grapevines, thus resulting in higher water potential in the leaves compared to plants in water-limited soil. In addition, grapevines in irrigated soils show higher uptake and transport of nutrients, such as nitrogen $(\mathrm{N})$, phosphorus $(\mathrm{P})$, potassium $(\mathrm{K})$, calcium $(\mathrm{Ca})$, and magnesium $(\mathrm{Mg})$, which preferentially accumulate in organs undergoing increased cell division, such as leaves and growing berries. However, if irrigated grapevines absorb high levels of certain nutrients, such as $\mathrm{N}$, increased plant growth would be expected, and thus,

IPrograma de Pós-graduação em Ciência do Solo, Universidade Federal de Santa Maria (UFSM), 97105-900, Santa Maria, RS, Brasil.

E-mail: mciotta@gmail.com. Corresponding author.

IIDepartamento de Solos, UFSM, Santa Maria, RS, Brasil.

IIILibera Università di Bolzano, Bolzano, Itália.

IVEmbrapa Clima Temperado, Pelotas, RS, Brasil.

vFondazione Mach san Michele all'Adige, Trento, Itália. 
a portion of the nutrients stored inside the berries may be reallocated to the growing organs. Furthermore, increased soil water availability due to irrigation can increase the moisture content inside plants, including inside the berries, thus increasing their diameter and weight. This phenomenon promotes sugar dilution, estimated by the total soluble solids (TSS) content, and increases the dilution of acids, especially malic acid, as estimated by total titratable acidity (CONDE et al., 2007). This study aimed to evaluate leaf water potential, nutritional status, and must composition in cv. 'Pinot Nero' grapevines grown with and without irrigation.

The experiment was conducted at a commercial vineyard of cv. 'Pinot Nero' 828, grafted on $\mathrm{SO}_{4}$ rootstock, established in 2002 in a Leptosol soil, in Trento, Northern Italy. Before establishing the experiment, the soil was characterized by 240,520 , and $240 \mathrm{~g} \mathrm{~kg}^{-1}$ of clay, silt, and sand, respectively; $\mathrm{pH}$ in water of $7.85 ; 2.4 \mathrm{~g}$ of total $\mathrm{N} \mathrm{kg}^{-1}, 289 \mathrm{mg}$ $\mathrm{kg}^{-1}$ of exchangeable $\mathrm{K}$ and $15 \mathrm{mg} \mathrm{kg}^{-1}$ of available $\mathrm{P}$; $13.6 \mathrm{cmol}_{\mathrm{c}}$ of $\mathrm{Ca} \mathrm{kg}^{-1}$; and $2.1 \mathrm{cmol}_{\mathrm{c}}$ of $\mathrm{kg}^{-1} \mathrm{Mg}$. In June 2013, randomized block design experiment was established, with five replicates of five plants each. The treatments were irrigated (I) and non-irrigated (NI). Leaf water potential $(\psi)$ was measured using a Scholander pressure chamber (VAN LEEUWEN et al., 2009), in July $\left(3^{\text {rd }}, 17^{\text {th }}\right.$, and $\left.26^{\text {th }}\right)$ and August $\left(2^{\text {nd }}\right.$, $14^{\text {th }}, 23^{\text {rd }}$, and $\left.28^{\text {th }}\right)$. The readings were taken from two fully expanded complete leaves per plant on two branches located in the middle portion, on all of the sides of the plant. Leaves and berries were collected in three times, August, September and October. Five leaves were collected at the middle portion of each branch, selected from both sides of the plant. The leaves were dried in a forced-air oven at $65^{\circ} \mathrm{C}$, ground, and digested with $\mathrm{HNO}_{3}$, in a microwave, after which they were analyzed for total levels of N, P, $\mathrm{Ca}, \mathrm{Mg}$, and $\mathrm{K}$ using inductively coupled plasma- and optical emission spectrometry (ICP-) OES). During the same leaf collection periods, 150 berries per plant were collected from the upper, middle, and lower portions of each grape cluster. The weight of 100 berries was determined using a digital scale. Then, the berries were crushed, and the total levels of N, P, $\mathrm{Ca}, \mathrm{Mg}$, and $\mathrm{K}$ were determined from a portion of the must using ICP-OES, after digestion with $\mathrm{HNO}_{3}$ in a microwave; a second portion of the must was used to evaluate total soluble solids ( $\mathrm{SST}$ ), $\mathrm{pH}$, and total titratable acidity. The results obtained were subjected to analysis of variance (ANOVA); when significant, the means were compared by Tukey's comparison test at $5 \%$ probability

The leaf water potential $(\psi)$ did not differ significantly at the first two assessments, July $3^{\text {rd }}$ and $17^{\text {th }}$, between the I and NI plants (Figure 1). Between

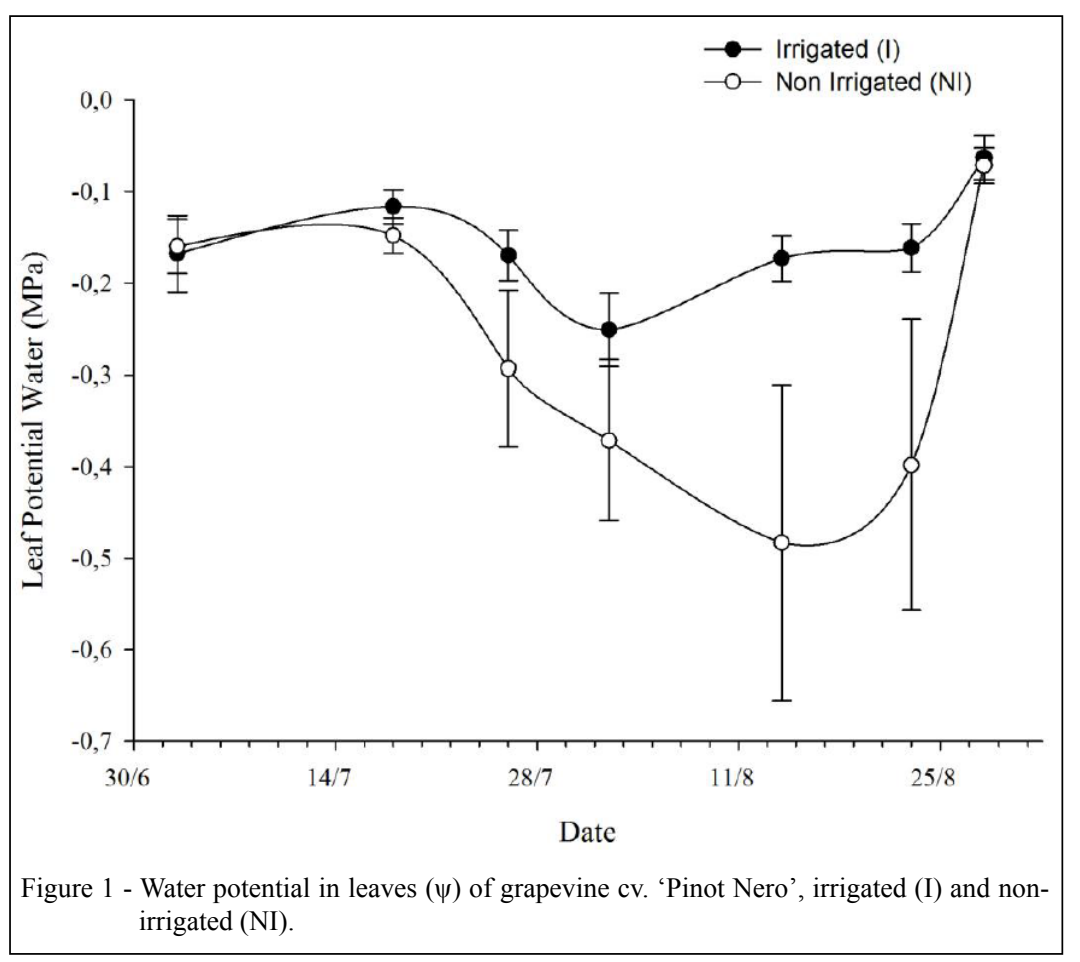

Ciência Rural, v.45, n.8, ago, 2015. 
July $17^{\text {th }}$ and August $23^{\text {rd }}, \psi$ was more negative in leaves of the NI plants, with the lowest $\psi,-0.5 \mathrm{MPa}$ for NI and -0.2 MPa for I. However, starting on August $28^{\text {th }}$, when rainfall of approximately $20 \mathrm{~mm}$ was observed and the soil moisture content likely increased in NI treatment, the leaf $\psi$ values did not statistically differ between the I and NI plants. The more negative $\psi$ values observed from July $17^{\text {th }}$ until August $28^{\text {th }}$ in leaves of the NI plants were likely due to the higher mean air temperature (mean of $22.3^{\circ} \mathrm{C}$ ) and lower relative humidity (69.29 and 62.90\%, respectively) in July and August, which promoted high vapor pressure deficits $(8.52$ and $10.51 \mathrm{hPa}$, respectively). Thus, lower water availability in the soil may have led to lower water uptake by plants, thus making $\psi$ in the plants more negative. The total levels of $\mathrm{K}, \mathrm{N}, \mathrm{P}, \mathrm{Ca}$, and $\mathrm{Mg}$ in the complete leaves were unchanged by irrigation in August, September, and October (Table 1), possibly because although the rainfall volume was not high in August, it may have been sufficient to maintain water availability in the NI soil, allowing for nutrient supply and uptake. Similarly, even without irrigation, adequately distributed rainfall of $69 \mathrm{~mm}$ in September and $127 \mathrm{~mm}$ in October was most likely sufficient to maintain soil moisture at the desired levels, thus favoring nutrient uptake by the grapevines. This is confirmed by the levels of $\mathrm{N}, \mathrm{P}, \mathrm{K}, \mathrm{Ca}$, and $\mathrm{Mg}$ in the leaves at the three collection periods (Table 1). Irrigation did not alter the total levels of $\mathrm{P}, \mathrm{K}$, and $\mathrm{Mg}$ in the berries (Table 1), which may be explained by the characteristics and way these nutrients accumulate in plants, especially in the grape clusters. During cluster development, the entry of water and nutrients via the xylem and phloem is the main mechanism of increasing volume and growth. After the berries change color, when the clusters ripen, certain nutrients (including $\mathrm{P}, \mathrm{K}$, and $\mathrm{Mg}$ ) continue to accumulate in the clusters via phloem. This is one reason why $\mathrm{K}$ is usually present at higher levels in clusters at harvest. Additionally, the total Ca content was higher in the berries of non-irrigated plants, which may be partially explained by the possible lower water availability in the soil, as indicated by the negative $\psi$ values in the complete leaves (Figure 1). However, the $\mathrm{Ca}$ content absorbed was sufficient and increased concentration on the berries. But as the levels were high there was no change in the levels in the leaves. During August and September, the total N levels in the berries were higher in the non-irrigated plants. This most likely occurred because the water content and the levels of mineral $\mathrm{N}$ forms available in the soil, especially of nitrate $\left(\mathrm{N}-\mathrm{NO}_{3}{ }^{-}\right)$, were adequate to meet the grapevines requirements, even in the NI treatment. In contrast, for the irrigated grapevines, it is possible that higher water availability in the soil potentiated the leaching of mineral forms of

Table 1 - Total content of nutrients in leaves and grapevine berries composition cv. 'Pinot Nero' irrigated (I) and non-irrigated (NI).

\begin{tabular}{|c|c|c|c|c|c|c|c|c|c|c|}
\hline Date & Trat. & $\mathrm{N}$ & $\mathrm{Ca}$ & $\mathrm{P}$ & $\mathrm{Mg}$ & $\mathrm{K}$ & $\begin{array}{l}\text { Weight } \\
100 \text { berries }\end{array}$ & TSS & $\mathrm{pH}$ & $\begin{array}{l}\text { Total titratable } \\
\text { acidity }\end{array}$ \\
\hline \multirow{3}{*}{ August } & \multicolumn{6}{|c|}{ - } & & & & \\
\hline & I & $25,4^{\mathrm{ns}}$ & $34,1^{\text {ns }}$ & $2,5^{\text {ns }}$ & $5,4^{\mathrm{ns}}$ & $10,0^{\text {ns }}$ & - & - & - & - \\
\hline & NI & 25,6 & 35,8 & 2,6 & 5,5 & 10,3 & - & - & - & - \\
\hline \multirow{2}{*}{ September } & I & $25,0^{\mathrm{ns}}$ & $34,7^{\text {ns }}$ & $1,6^{\mathrm{ns}}$ & $5,3^{\text {ns }}$ & $9,7^{\mathrm{ns}}$ & - & - & - & - \\
\hline & NI & 25,1 & 34,6 & 1,6 & 5,5 & 10,9 & - & - & - & - \\
\hline \multirow{3}{*}{ October } & I & $21,6^{\mathrm{ns}}$ & $37,9^{\text {ns }}$ & $1,5^{\mathrm{ns}}$ & $5,5^{\mathrm{ns}}$ & $9,7^{\mathrm{ns}}$ & - & - & - & - \\
\hline & NI & 21,8 & 36,5 & 1,4 & 5,3 & 9,7 & - & - & - & - \\
\hline & \multicolumn{6}{|c|}{--Berries, $\mathrm{g} \mathrm{kg}^{-1} \mathrm{DM}-$} & $\mathrm{g}$ & $\operatorname{Brix}^{\circ}$ & & $\mathrm{g} \mathrm{L}^{-1}$ \\
\hline \multirow{2}{*}{ August } & I & $4,2 b^{(1)}$ & $1,2 \mathrm{~b}$ & $0,8^{\text {ns }}$ & $0,6^{\mathrm{ns}}$ & $13,4^{\text {ns }}$ & 88 & 14,0 & & 14,2 \\
\hline & NI & $6,0 \mathrm{a}$ & $1,6 \mathrm{a}$ & 0,9 & 0,8 & 14,9 & 87 & 13,6 & & 16,2 \\
\hline \multirow{2}{*}{ September } & I & $4,2 b$ & $0,7^{\text {ns }}$ & $0,7^{\mathrm{ns}}$ & $0,5^{\mathrm{ns}}$ & $11,0^{\mathrm{ns}}$ & 115 & 18,1 & 3,26 & 7,4 \\
\hline & NI & $4,7 \mathrm{a}$ & 0,7 & 0,7 & 0,5 & 11,8 & 149 & 17,0 & 3,21 & 8,2 \\
\hline \multirow[b]{2}{*}{ October } & I & $4,4^{\mathrm{ns}}$ & $0,7^{\mathrm{ns}}$ & $0,7^{\mathrm{ns}}$ & $0,5^{\mathrm{ns}}$ & $10,7^{\mathrm{ns}}$ & $161^{\mathrm{ns}}$ & $22,8^{\mathrm{ns}}$ & $4,02^{\mathrm{ns}}$ & $4,0^{\mathrm{ns}}$ \\
\hline & NI & 4,4 & 0,7 & 0,7 & 0,5 & 10,8 & 157 & 20,9 & 3,86 & 4,0 \\
\hline
\end{tabular}

${ }^{(1)}$ Means followed by the same letter in the column do not differ by Tukey test $(\mathrm{P}<5 \%)$. ns $=$ not significant.I $=$ irrigated, NI $=$ non irrigated. 
$\mathrm{N}$ in the soil, especially $\mathrm{N}-\mathrm{NO}_{3}^{-}$, which forms an outer sphere complex with the reactive particles in the soil. Thus, the $\mathrm{N}$ availability is reduced and, consequently, the amount absorbed and accumulated in grapevine organs decreases, including in the berries (BRUNETTO et al., 2006).

Irrigation also did not alter the weight of 100 berries or the $\mathrm{pH}$, TSS, or total titratable acidity values in the must (Table 1). One explanation for the consistent weight of 100 berries is that the rainfall was approximately $57 \mathrm{~mm}$ throughout August, which may have provided sufficient water to maintain adequate availability in the soil and supply to the plants. Sufficient water supply for plants allows for adequate rates of photosynthesis and sugar synthesis, promoting growth and increased cluster weight. However, despite these potential benefits of irrigation, there was no increase in the weight of 100 berries, which may explain the absence of an effect of irrigation on TSS content (COSTELLO \& PATTERSON, 2012). The fact that plants may not have been stressed due to lack of water may explain the absence of effects of irrigation on $\mathrm{pH}$ and total titratable acidity (ETCHEBARNE et al., 2010). Although it produced a less negative water potential for the grapevine leaves, irrigation did not affect nutritional status or must composition, and it only slightly changed the berry nutrient content.

\section{ACKNOWLEDGEMENTS}

The authors thanks Coordenação de Aperfeiçoamento de Pessoal de Nível Superior (CAPES) for its financial support (CAPES, Processo BEX 11571/13-6).

\section{REFERENCES}

BRUNETTO, G. et al. Recuperação e distribuição do nitrogênio fornecido a videiras jovens. Pesq agropec bras, v.41, n.8, p.1299-1304, 2006. Available from: <http:/www.scielo.br/ scielo.php?pid $=$ S0100-04X2006000800013\& script $=$ sci arttext>. Accessed: Ago. 01, 2014. doi.org/10.1590/S0100204X2006000800013.

CONDE, C. et al. Biochemical changes throughout grape Berry development and fruit and wine quality. Food, v.1, n.1, p.1-22, 2007. Available from: $<\mathrm{http} / / \mathrm{www}$.scielo.br/scielo.php?script=sci nlinks\&ref $=000091 \&$ pid $=$ S0100-204X201200020000800006\&lng $=$ en $>$. Accessed: Ago. 01, 2014.

COSTEllo, M.J.; PATTERSON, K. Regulated deficit irrigation effect on yield and wine color of Cabernet Sauvignon in Central California. Hortscience, v.47, n.10, p.1520-1524, 2012. Available from: <http://hortsci.ashspublications.org/ content/47/10/1520.short>. Accessed: Ago. 01, 2014.

ETCHEBARNE, F. et al. Leaf: fruit ratio and vine water status effects on Grenache Noir (Vitis vinfera L.) Beny composition: water, sugar, organic acids and cations. S Afr J Enol Vitic, v.31, p.106-115, 2010.

MARIANI, L. et al. Climate change in Europe and effects on thermal resources for crops. International Journal of Biometeorology, v.56, p.1123-1134, 2012. Available from: <http:// link.springer.com/article/10.1007/s00484-012-0528-8>. Accessed: Ago. 01, 2014 doi: 10.1007/s00484- 012-0528-8.

VAN LEEUWEN, C. et al. Vine water status is a key factor in grape ripening and vintage quality for red Bordeaux wine. How can it be assessed for vineyard management purposes. J Int Sci Vigne Vin, v.43, p.121-134, 2009. Available from: <http://www.oliviertregoat. com/vine_water_status_is_a_key_factor.pdf $>$. Accessed: Ago. 15, 2014. 